\title{
Shareholder voting and merger returns
}

\author{
Laura Sophie Henning ${ }^{1}$
}

\begin{abstract}
Using a sample of 384 shareholder meetings, I investigate whether shareholder votes on mergers and acquisitions in both target and acquirer firms are related to announcement day abnormal returns and whether the voting outcome has implications for the short- and long-run merger performance. I find that shareholder voting dissent is negatively related to both abnormal returns upon merger announcement and recommendations by the Institutional Shareholder Services. The former relationship is stronger for target firms and only borderline significant for acquirer firms. Overall, shareholders seem to take both advisor opinions and market beliefs into account when taking their voting decision. I also find that cumulative abnormal returns on the meeting date are strongly positively related to voting dissent. The observed relationship holds only for mergers with a long negotiation period, suggesting that in these mergers a higher fraction of residual uncertainty is resolved with a "pass" vote. Furthermore, I find that voting dissent is negatively related to long-run abnormal merger performance, suggesting a predictive power of merger votes.
\end{abstract}

Keywords Shareholder voting - Mergers and acquisitions · Proxy advisors · Monitoring $\cdot$ Merger performance

JEL Classification $\mathrm{G} 14 \cdot \mathrm{G} 34$

\section{Introduction}

A number of high-profile accounting scandals and perceived corporate governance failures have led shareholders to exert more influence on firm decisions via votes

$凶 \quad$ Laura Sophie Henning laura.henning@unisg.ch

1 Swiss Institute of Banking and Finance, University of St. Gallen, Rosenbergstrasse 52, 9000 St. Gallen, Switzerland 
(Guercio et al. 2008; Ferri and Sandino 2009). Accordingly, shareholder voting and its determinants have received increasing attention in the literature (Gordon and Pound 1993; Gillan and Starks 2000; Fischer et al. 2009; Choi et al. 2010). In particular, votes on corporate decisions such as director elections, compensation, and shareholder proposals have been extensively studied (Cai et al. 2009; Cunat et al. 2012; Ertimur et al. 2013). Corporate transactions, however, which are arguably some of the most far-reaching corporate decisions, have been largely neglected by the literature to date.

Using a sample of 384 shareholder votes on mergers and acquisitions, I first investigate the determinants of shareholder voting decisions, in particular whether voting dissent depends on the merger announcement returns, Institutional Shareholder Services (ISS) recommendation, and various deal and firm characteristics. Notably, in mergers and acquisitions, target and acquiring firms are subject to different legal regulations. Target firms are obliged to hold a vote; acquirer shareholder approval is only required when more than $20.0 \%$ of outstanding shares are to be issued to facilitate the merger. ${ }^{1}$ Further, target and acquirer shareholder voting decisions may be driven by different motives. Therefore, throughout this paper, I separately investigate shareholder votes held at target and acquiring firms. My findings show that positive recommendations by ISS are significantly negatively associated with shareholder voting dissent for both targets and acquirers. Further, I find a significant and negative relation between announcement abnormal returns and voting dissent, which is stronger in target shareholder votes. Second, I analyze the effect of voting dissent on abnormal returns around the shareholder meeting. I find that voting dissent is positively related to cumulative abnormal returns on the meeting date. However, this relationship holds only for mergers with high uncertainty (measured by the length of the negotiation period), suggesting that high expected shareholder dissent might, to some degree, reflect an uncertainty discount to the stock price, which is resolved upon the vote. Finally, I investigate the relationship between voting dissent in acquirer firms and subsequent long-term merger performance over 2- and 5-year holding periods. I find that voting dissent is negatively related to long-run abnormal merger performance, suggesting that mergers receiving stronger support, as measured by shareholder votes, perform better in the long run.

My study contributes to the large literature on shareholder voting and its determinants. Recent research suggests that proxy advisor recommendations are the most important source of information for shareholders (Choi et al. 2010; Ertimur et al. 2013). However, other aspects relevant to the specific context of the vote, such as governance structures, firm and director performance, management entrenchment, ownership structure, and size, have been found to influence shareholder voting decisions (Gordon and Pound 1993; Gillan and Starks 2000; Cai et al. 2009; Fischer et al. 2009). I add to this literature by showing that abnormal returns upon merger announcement are negatively related to shareholder voting dissent, particularly in target firms,

\footnotetext{
1 This applies to all firms listed on one of the major US stock exchanges; see NYSE Company Manual, Section 312.03, AMEX Company Guide, Section 712, and NASDAQ Marketplace Rules, Section 4350.
} 
suggesting that shareholders are aware of and account for market opinion when voting on mergers. ${ }^{2}$

My paper is also related to the literature investigating stock market reactions to merger announcements. Evidence suggests that merger announcements, on average, do not create value for acquirer shareholders (Travlos 1987; Amihud et al. 1990; Andrade et al. 2001). Target firms, however, on average experience highly positive abnormal returns upon announcement (Andrade et al. 2001). I add to this literature by showing that these abnormal announcement returns have implications for subsequent shareholder votes and that a larger shareholder dissent may be associated with a higher fraction of uncertainty that is resolved upon the shareholder vote.

Finally, my study also contributes to the literature investigating long-run merger performance. For example, Agrawal et al. (1992), Rau and Vermaelen (1998), Andrade et al. (2001), and Moeller et al. (2005) document that mergers severely underperform in the long term. Adding to this evidence, I show that voting dissent is negatively related to long-term abnormal merger performance, suggesting that shareholders are able to discern between "good" and "bad" mergers.

The paper most closely related to mine is Becher et al. (2011), which focuses on how financial advisor opinions impact acquirer shareholders' voting behavior. The authors use hand-collected data of financial advisor opinions on 136 mergers announced between 2000 and 2006 in which both target and acquirer hire at least one financial advisor. They find that target advisor opinions, but not acquirer advisor opinions, significantly impact acquirer shareholder voting, and that acquirer advisor opinions negatively relate to post-merger performance. My paper extends Becher et al. (2011) by analyzing abnormal announcement returns as a direct driver of voting results, investigating the impact of proxy advisors instead of financial advisors, and investigating a larger sample of acquirers. Moreover, in my study, I investigate both acquirers and targets in separate analyses. This is important because shareholders of target firms are likely to judge transactions very differently than will shareholders of acquiring firms. The former have a higher incentive to closely monitor the transaction process since their ownership in the target firm ceases with completion of the transaction. While management may have an incentive to lobby for shareholder approval, possibly weakening the link between market and proxy advisor opinions and shareholder votes, I find that market reactions to merger announcements as well as proxy advisor recommendations significantly affect voting behavior, particularly in target firms. Finally, I further extend the work of Becher et al. (2011) by investigating the direct market response to shareholder votes around the shareholder meeting date. I find that the market reacts positively to resolved uncertainty reflected by high voting dissent.

The remainder of this paper is organized as follows. Section 2 provides a literature review and derives testable hypotheses. In Sect. 3, I describe my dataset, variable construction, and methodology. Section 4 presents the empirical results. I conclude in Sect. 5 .

\footnotetext{
${ }^{2}$ Either they observe and account for the merger announcement return or they are exposed to or seek the same information, which is reflected in the observed merger announcement returns.
} 


\section{Literature review and hypotheses}

Proxy advisor recommendations are the most important source of information for shareholders when deciding how to vote in shareholder meetings (Choi et al. 2010; Ertimur et al. 2013). However, recent research suggests that in determining their voting decision, shareholders also take into account various other aspects relevant to the specific context of the vote.

The determinants of shareholder votes have been mainly studied in the context of shareholder proposals, director elections, and say-on-pay votes. In votes on governance-related proposals sponsored by shareholders, Gordon and Pound (1993) find that governance structure and firm performance positively relate to shareholder support. In uncontested director elections, Cai et al. (2009) and Fischer et al. (2009) show that firm and director performance positively relate to shareholder voting support. Further, Cai et al. (2009) find that measures of management entrenchment are negatively associated with voting support. Fischer et al. (2009) show that director approval rates are strongly positively related to approval rates of other directors at the same firm, which is consistent with investors assessing the governing team as a whole. In say-on-pay votes, Ertimur et al. (2013) find that various firm characteristics, such as institutional ownership, size, and performance, seem to affect the sensitivity of voting outcomes to proxy advisor recommendations. More generally, across different types of shareholder votes, board and institutional ownership seem to affect voting outcomes (Gordon and Pound 1993; Gillan and Starks 2000; Cai et al. 2009; Ertimur et al. 2013).

In the context of mergers and acquisitions, acquirer shareholder votes have been found to be strongly related to target advisor opinions, but not to acquirer advisor opinions (Becher et al. 2011). Moreover, I would expect acquirer shareholders to take the abnormal announcement returns associated with the transaction into account when voting on the transaction. Alternatively, acquirer shareholders may rely on the same sources of information, for example, press coverage, analyst reports, and the like, which are already reflected in the abnormal returns to the merger announcement when making their voting decision. Hence, the first testable hypothesis is:

H1a: Mergers that experience higher abnormal announcement returns will receive less voting dissent by acquirer shareholders.

When making their voting decisions, I would expect that target shareholders evaluate abnormal announcement returns in a manner similar to that done by acquiring firms. However, shareholders of target firms are expected to monitor the transaction process more closely since their ownership in the target firm ceases with completion of the transaction. I would, therefore, expect the relationship between abnormal announcement returns and voting dissent to be stronger for target firms than for acquiring firms. This leads me to the second testable hypothesis:

H1b: The negative relationship between abnormal announcement returns and voting dissent will be stronger for target than for acquiring firms. 
Previous literature reports mixed evidence on abnormal returns following shareholder votes. Most studies in this context focus on shareholder proposals. Karpoff et al. (1996) and Bizjak and Marquette (1998) find weak positive abnormal returns following the pass of shareholder proposals. ${ }^{3}$ Cai and Walkling (2011) find positive abnormal returns following the defeat of activist-sponsored say-on-pay proposals. The authors argue that shareholders were discontent that activists mainly targeted large firms, and not those firms with an actual "need" for reforms (such as firms with excessive CEO pay, poor governance, or poor performance). Most recently, Cunat et al. (2012, 2013), using a regression discontinuity approach, find positive abnormal returns following shareholder meetings where votes on shareholder-initiated governance proposals and say-on-pay policy proposals passed by a small margin, compared to meetings where votes failed by a small margin.

Voting dissent can be a possible avenue for shareholders to express their discontent. If shareholders have concerns about a forthcoming deal but are not able to "block" it, I would expect to observe a negative market reaction following the meeting. In contrast, however, I might expect to observe a positive market reaction to high voting dissent-for at least two reasons. First, the shareholder meeting resolves residual uncertainty regarding merger completion. If uncertainty is reflected in higher shareholder opposition, I should observe a positive market reaction with regard to mergers that pass despite high dissent. Second, shareholder voting is a monitoring mechanism and disciplinary votes appear to be followed by positive abnormal returns (Cai and Walkling 2011; Cunat et al. 2012). If monitoring is reflected in higher shareholder opposition, I should observe a positive market reaction following high dissent. Hence, I have two competing hypotheses on the relation between voting dissent and abnormal meeting returns that I will test separately for target and acquiring firms:

H2a: Among mergers that pass, those that receive greater voting dissent will experience lower (or negative) abnormal meeting returns.

$\mathrm{H} 2 \mathrm{~b}$ : Among mergers that pass, those that receive greater voting dissent will experience higher abnormal meeting returns.

Existing research suggests that, on average, acquirers significantly underperform in the long run (Agrawal et al. 1992; Rau and Vermaelen 1998). Moeller et al. (2005) find that this is particularly true for acquisitions with large shareholder wealth losses upon announcement (in excess of USD 1 billion). One possible reason for this underperformance is managerial empire-building behavior (Jensen 1986; Masulis et al. 2007; Hope and Thomas 2008). Consistently, Masulis et al. (2007) show that well-governed firms are less likely to engage in value destroying acquisitions, as measured by the short-term announcement return to the transaction. If shareholders are able to discern "good" value-creating from "bad" empire-building acquisitions, their voting dissent should be significantly related to the acquirers' post-merger long-term performance. This leads me to the third testable hypothesis:

\footnotetext{
3 Bizjak and Marquette (1998) find positive abnormal returns around the proxy mailing day and only weak abnormal returns on the meeting day for shareholder proposals to revoke poison pills. They hypothesize that most of the relevant information about the proposal has already been released to the market at the time of the proxy mailing.
} 
H3: Mergers that receive greater voting dissent will perform worse in the long run than mergers that receive less voting dissent.

\section{Data and variable construction}

\subsection{Data}

I use data on M\&A votes from the Institutional Shareholder Services Voting Analytics Database. This database contains information on ballot items and voting outcomes. The data include meetings held between 2003 and 2011 at firms included in the Russell 3000 index. Out of the 171 different types of management-sponsored votes that Voting Analytics classifies, I include the two categories "Approve Merger Agreement" (M0405) and "Approve Acquisition or Issue Shares in Connection with Acquisition" (M0410) in my sample. This yields 624 observations of shareholder meetings on M\&A held at both target and acquiring firms. I exclude not disclosed (88), incomplete (45), or not identifiable (29) merger observations, as well as duplicates (11). This reduces my sample to 451 shareholder meeting observations. I identify the transaction counterparty in proxy filings and manually match these meeting events in Voting Analytics to the Securities Data Corporation Platinum M\&A data on deal characteristics. I exclude transactions with the sole purpose of changing the state of incorporation (19) as well as those with ownership of less than $90 \%$ after the transaction (11). Because of the different nature of regulated businesses and their financial data, I exclude deals in which one of the parties is a utility firm (21). In unreported robustness tests, I also exclude mergers in which one of the parties is a financial firm and find the results to remain virtually unchanged. Most of my sample firms have only one merger observation in the sample. There are 22 firms for which I have two recorded deals. None of the deals in my sample is hostile or based on a tender offer.

I then combine the voting data on the remaining 400 observations with additional data from the Center for Research for Security Prices (CRSP), Compustat, and Datastream. I require 155 trading days of return observations prior to the merger announcement. I hand-collect data on CEO and director ownership from the most recent proxy filing prior to the vote. ${ }^{4}$ For firms that have more than one class of shares with different voting rights, I adjust the number of shares by the respective voting power of each share class. My final sample consists of 141 firm votes that are held in target firms and 243 firm votes held in acquiring firms. The total of 384 firm votes span 367 transactions. Therefore, in only 17 transactions are both counterparty votes (of target and acquirer) included in my sample. There are two reasons for this low overlap. First, private firms are not obliged to hold shareholder meetings and, if they do, they are not included in Voting Analytics: $24.3 \%$ of the acquirers in my sample purchase a target that is privately held. ${ }^{5}$ Second, the major US stock exchanges require

\footnotetext{
4 Execucomp covers only firms included in the S\&P 1500 Index. Further, ownership stakes are registered only for the top five executive officers within a firm.

5 The remaining $75.7 \%$ of acquirers in my sample purchase a public target. The respective target voting outcomes are to a large extent not included in my sample because either the target firm is not covered by ISS or the voting outcome is missing or marked "not disclosed" in the ISS data.
} 
shareholder approval of mergers and acquisitions for acquirer firms only when more than $20.0 \%$ of outstanding shares are to be issued. ${ }^{6}$

\subsection{Voting measures}

Voting outcomes are reported in three categories: "For," "Against," and "Abstain." When shareholders receive the proxy cards they can either mark "For," "Against," or "Abstain" and return their card. If a shareholder fails to return the card, his or her vote will be counted as "Not Voted." On routine matters, votes can be cast actively by shareholders or by brokers for those shares held in street name. However, management proposals on mergers are classified as non-routine.

Following previous research (Martin and Thomas 2005; Morgan et al. 2006; Ertimur et al. 2012; Ferri and Maber 2013), I investigate the voting dissent expressed by shareholders. I measure dissent as the number of shares voted "Against" relative to the sum of shares voted "For" and "Against." In unreported regressions, I additionally include the number of shares voted "Abstain" in both the numerator and the denominator and find my results to remain very similar. ${ }^{7}$

I also construct two alternative measures of voting dissent that account for ownership structure. Since my sample contains only friendly mergers, management can be expected to vote in favor of all deals (Becher et al. 2011). Similar to Becher et al. (2011), I first exclude the stake held by all directors and executives (including the CEO) by subtracting their stake from the voting base. Further, if a bidding firm already holds a "toehold" stake in the target firm, it will most likely vote these shares in favor of a deal. Thus, in a second step, I adjust the voting base of target firms by excluding this toehold from the voting base. All voting dissent measures are winsorized at the $1 \%$ level to avoid having outliers drive my results.

Panel A of Table 1 shows that the 141 target firms in my sample on average receive $2.9 \%$ voting dissent of $2.9 \%$. The 243 acquiring firms experience on average a slightly lower voting dissent of $2.3 \%{ }^{8}$ Mean and median dissent are fairly low but the range of voting outcomes is quite large. The 90th dissent percentile is at $8.9 \%$ for target and at $6.5 \%$ for acquiring firms. However, shareholders do not seem to strongly disagree with management in most of the observed mergers.

\subsection{Abnormal returns}

Three dates are relevant to my study: the announcement, meeting, and completion dates. First, the merger is announced to the public. Initial market reaction to the merger is reflected in the abnormal announcement day returns. Both targets and acquirers then pass a resolution adopting a plan of merger that specifies the parties involved as well as details of the transaction. Second, the merger is voted on at a shareholder meeting.

\footnotetext{
6 This applies to all firms listed on one of the major US stock exchanges; see NYSE Company Manual, Section 312.03, AMEX Company Guide, Section 712, and NASDAQ Marketplace Rules, Section 4350.

7 The Pearson correlation between the two measures of voting dissent is 0.94 .

8 The mean difference in voting dissent between targets and acquirers is significant at the $10 \%$ level.
} 


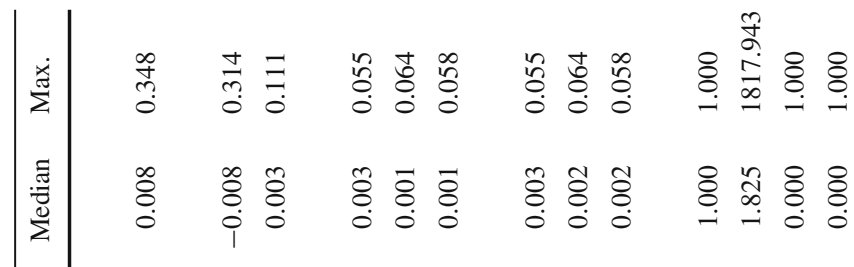

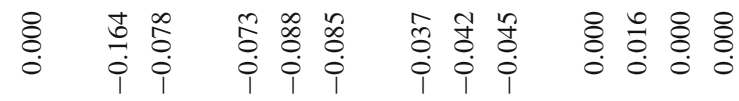

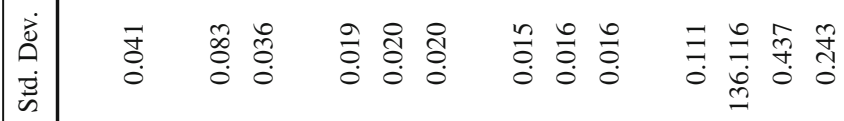

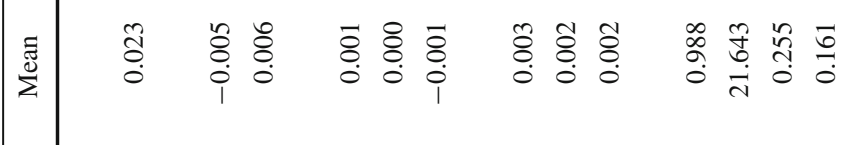

苟

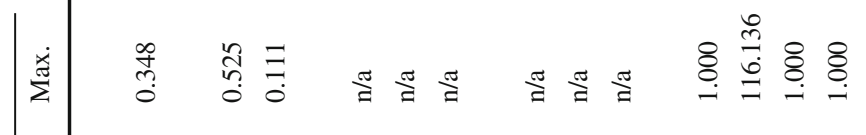

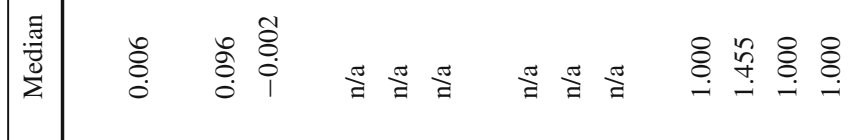

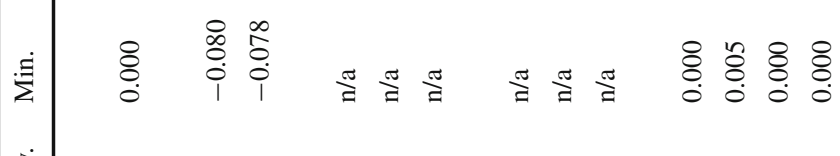

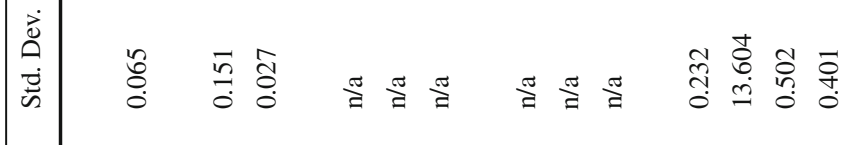

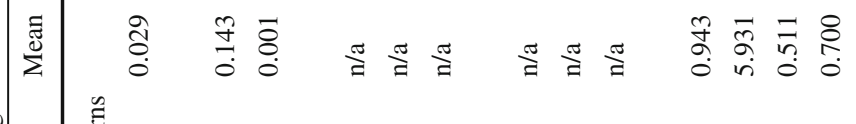
竞

E $\quad$ b $\quad \Leftrightarrow$ 


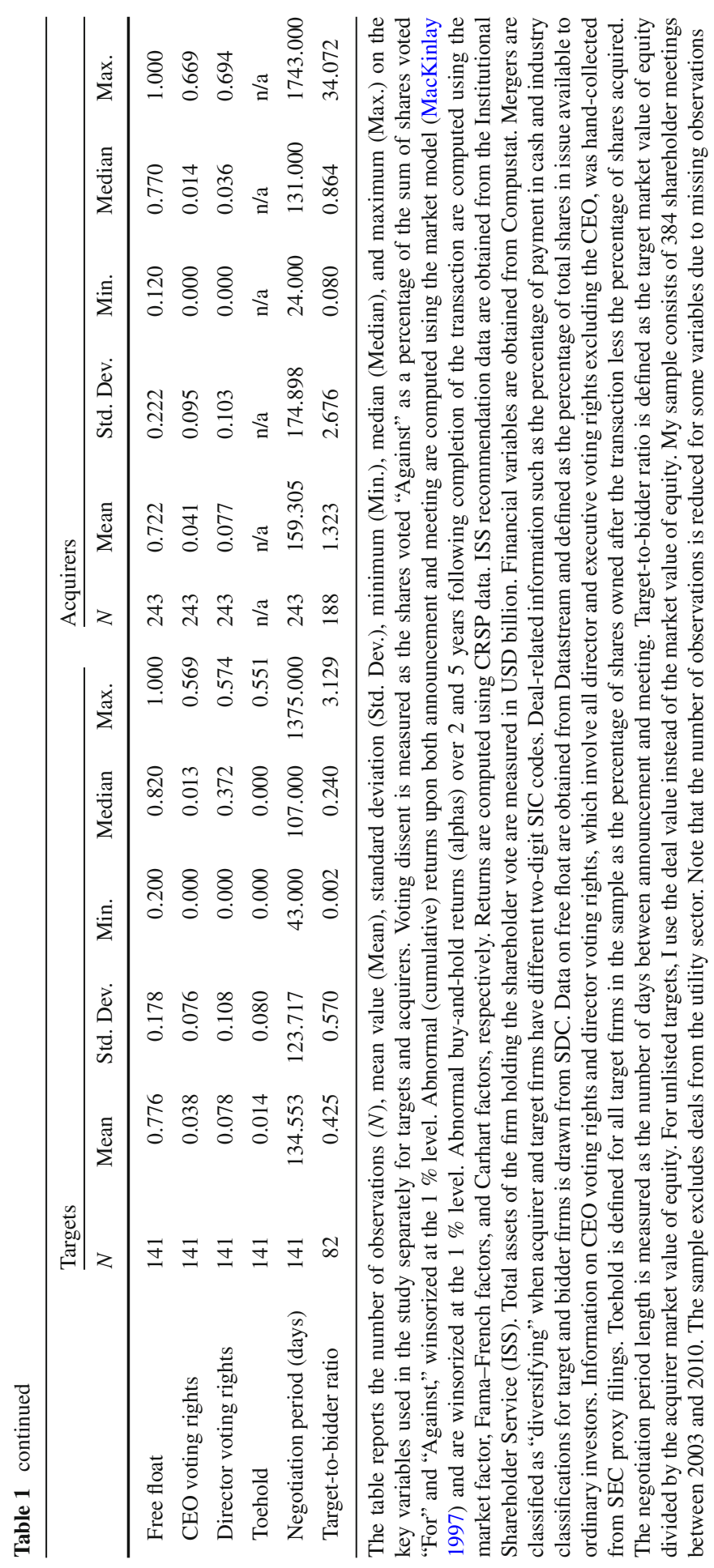


Information about deal specifics as well as the time and place of the meeting will be provided in the definitive proxy statements filed as required by Section 14(a) of the Securities Exchange Act of 1934. In my sample, the average time between merger announcement and shareholder meeting is 150 days. The market response to passing a merger is measured by the abnormal meeting day return. Third, the merger becomes effective at a determined completion date following the shareholder meeting. I estimate the long-run performance beginning in the first calendar month following the month of merger completion.

I estimate abnormal returns on announcement and meeting days using standard short-term event study methodology (MacKinlay 1997). I apply the market model to estimate firm-specific abnormal returns using the CRSP value-weighted index and a 125-trading-day period ending 30 trading days before the event date. The event windows are defined as Day 0 (merger announcement) and Day $0+$ Day 1 (meeting). For the meeting, I estimate cumulative abnormal returns for a two-day window since voting results are not always available on the day of the meeting (Karpoff et al. 1996). All abnormal returns are winsorized at the $1 \%$ level. To investigate acquirer long-term performance, I estimate 2- and 5-year buy-and-hold returns using monthly returns starting in the first calendar month after the month in which the merger became effective. I use three alternative benchmark models: the market model, the Fama and French (1993) three-factor model, and the Carhart (1997) four-factor model.

Panel A of Table 1 shows that the target firms in my sample experience on average abnormal returns of $14.3 \%$ upon announcement of the merger, while acquiring firms experience $-0.5 \%$ on average. ${ }^{9}$ Cumulative abnormal returns around the shareholder meeting date are substantially lower and amount to $0.1 \%$ on average for target firms and $0.6 \%$ for acquiring firms for the two-day event window.

Over holding periods of 2 and 5 years following merger completion, the acquiring firms in my sample experience buy-and-hold abnormal returns of 0.1 and $0.3 \%$, respectively, when accounting for the market factor. When estimating the regression intercepts using the Fama-French three-factor model, I observe abnormal returns of 0.0 and $0.2 \%$ over the two holding periods. Similarly, buy-and-hold abnormal returns amount to -0.1 and $0.2 \%$, respectively, when I additionally account for the Carhart (1997) momentum factor. This is substantially higher (i.e., less negative) than the underperformance of roughly $10 \%$ for the 5-year post-merger period estimated by Agrawal et al. (1992) over the time period 1955-1987, and the underperformance of $4 \%$ for the 3-year post-merger period estimated by Rau and Vermaelen (1998). ${ }^{10}$

\footnotetext{
9 The mean difference in announcement returns between targets and acquirers is significant at the $1 \%$ level.

10 Agrawal et al. (1992) use a sample of mergers between NYSE acquirers and NYSE/AMEX targets. The authors employ two methodologies, both measuring stock performance after subtracting a benchmark return adjusted for beta risk and market capitalization. First, they use the methodology of Dimson and Marsh (1986) and Lakonishok and Vermaelen (1990). The second methodology extends the returns across time and securities (RATS) methodology of Ibbotson (1975) by an adjustment for firm size. The authors account for size by creating ten decile portfolios according to firm market capitalization for all stocks on the NYSE at the end of each calendar year. For each month over the following year, the return on each portfolio is estimated as the equally weighted average return. Rau and Vermaelen (1998) track acquirer performance relative to equally weighted control portfolios with similar size and book-to-market over a period of 3 years after the merger completion date.
} 


\subsection{Control variables}

The construction of control variables is based on previous research on both mergers and acquisitions and shareholder voting. I include several deal- and firm-specific measures. I control for whether a deal received a recommendation to vote "For" by Institutional Shareholder Services, the most influential proxy advisor. Panel B of Table 1 shows that $94.3 \%$ of all target votes and $98.8 \%$ of acquirer votes in my sample receive such a recommendation. I control for firm size using the natural logarithm of total assets. On average, target and acquiring firms in my sample have total assets of USD 5.9 billion and USD 21.6 billion, respectively. Further, deals are classified as "diversifying" when acquirer and target firms have different two-digit SIC codes. In my sample, $51.1 \%$ of deals covered by target votes and $25.5 \%$ of deals covered by acquirer votes are diversifying. I account for the deal's payment type using the percentage of the deal value paid in cash. In deals on which target shareholders vote, on average $70.0 \%$ of the deal value is paid in cash, whereas in deals on which acquirer shareholders vote, only $16.1 \%$ of deal value (on average) is paid in cash. I also collect data on firm ownership structure. First, I control for the shares in free float using the percentage of total shares in issue available to ordinary investors. In my sample, target and acquiring firms have on average 77.6 and $72.2 \%$ of their shares in free float, respectively. Second, I control for insider voting rights held by the CEO, other top executives, and by the board of directors. CEO voting rights are defined as the percentage of shares held by the CEO. Director voting rights denote all voting rights held by all top executives and directors as a group, excluding the CEO. For the average target (acquiring) firm in my sample, $3.8 \%$ (4.1\%) of voting rights are held by the CEO, and $7.8 \%$ (7.7 \%) are held by all other executives and directors as a group. $\mathrm{CEO}$ and director ownership stakes range up to nearly $70 \%$ in my sample. I estimate the toehold for all target firms in my sample as the percentage of shares owned after the transaction less the percentage of shares acquired. The average toehold stake held in the target firms in my sample is $1.4 \%$. I account for the negotiation period using the number of days between merger announcement and meeting date. On average, it took 134.6 days to negotiate the deals for the targets in my sample, and 159.3 days for the acquirers. I also collect data on the relative size of target to acquiring firm by calculating the ratio of the target's market value of equity to the acquirer's market value of equity. If, for the acquirers in my sample, target market value of equity is unavailable I use the deal value instead. For the target firms included in my sample, the target-to-bidder ratio is $42.5 \%$ on average, while for acquirers it amounts to $132.3 \%$. This high ratio is most likely due to the regulatory setting requiring a shareholder vote only in deals where more than $20.0 \%$ of stock is to be issued.

\section{Empirical results}

\subsection{Voting outcome and abnormal announcement returns}

In this section, I investigate the determinants of shareholder voting decisions in target and acquirer firms. I regress voting dissent at the shareholder meeting on abnormal announcement returns at the merger announcement and various control variables. The 
dependent variable is measured as the shares voted "Against" as a percentage of the sum of shares voted "For" and "Against." I include deal- and firm-specific measures as independent variables. My baseline specification includes the abnormal announcement returns, a dummy indicating whether the deal received a "For" recommendation by ISS, and a proxy for firm size. In other specifications, I include diversification, payment type, and negotiation period as additional deal-specific controls, and free float and CEO and director ownership as firm-specific variables. I estimate all regressions including industry- and year-fixed effects and use White (1980) heteroskedasticityrobust standard errors.

The results for target (Columns 1 and 2) and acquirer (Columns 3 and 4) firms are reported in Table 2. Overall, I find that both the ISS recommendation and abnormal announcement returns are negatively related to voting dissent in all four columns. This is consistent with $\mathrm{H} 1 \mathrm{a}$, which states that acquirer shareholders take market beliefs into account when making their voting decisions. Moreover, and in support of H1b, I find that the relationship between abnormal announcement returns and voting dissent is stronger and more significant for targets than for acquirers. This may be due to pronounced monitoring by target shareholders. Further, ISS recommendations are significantly related to voting, dissent with the respective coefficient being significant at least at the $5 \%$ level for both targets and acquirers. Previous literature points to the importance of proxy advisor services (most importantly ISS) in influencing shareholder votes. For example, Choi et al. (2010) and Ertimur et al. (2013) find that proxy advisor recommendations strongly relate to shareholder support in uncontested director elections and say-on-pay votes, respectively. Still I find that, controlling for the ISS proxy advisor recommendation, the abnormal announcement return to the merger explains a significant portion of shareholder voting dissent (in target firm votes). Further, for acquirers, I find a positive and significant relationship between free float and voting dissent. Hence, a higher percentage of widely dispersed (often private) shareholders is positively related to observed voting dissent. This finding is consistent with Gordon and Pound (1993) and Gillan and Starks (2000), both reporting that institutions tend to vote alongside management. Specifically, they report that institutional ownership is positively related to the percentage of votes cast for shareholder proposals. ${ }^{11}$ Results are qualitatively similar when I use blockholder data from the Thomson Reuters 13F Institutional Holdings (formerly CDA/Spectrum) Database instead of free float. Further, I document a negative and significant relationship between CEO voting rights and voting dissent for acquiring firms. Given that my sample contains only friendly, management-sponsored transactions, it can be expected that CEOs vote their shares in favor of the deals they propose.

I perform a number of robustness tests on this first set of main results. First, I estimate tobit instead of OLS regressions as the dependent variable is bound to values between zero and one. As reported in Columns 1-4 of Table 3, the results are robust

\footnotetext{
11 Moreover, individual investors do not vote as frequently as institutional shareholders, who are legally required to vote. Proxy voting is subject to Employment Retirement Income Security Act (ERISA) fiduciary responsibility rules for pension funds (1974), the SEC Proxy-Voting by Investment Advisers rule (2003), and SEC Rule 206(4)-6 of the Investment Advisors Act of 1940. These regulations require funds to vote in the best interest of their clients.
} 
Table 2 Voting dissent

\begin{tabular}{|c|c|c|c|c|}
\hline & \multicolumn{2}{|l|}{ Targets } & \multicolumn{2}{|l|}{ Acquirers } \\
\hline & (1) & (2) & (3) & (4) \\
\hline Intercept & $\begin{array}{l}0.110 * * \\
\quad(1.993)\end{array}$ & $\begin{array}{l}0.083 \\
\quad(1.343)\end{array}$ & $\begin{array}{r}0.131 * * * \\
(4.614)\end{array}$ & $\begin{array}{r}0.119 * * * \\
(4.577)\end{array}$ \\
\hline Abnormal ARs & $\begin{array}{r}-0.098 * * * \\
(-2.666)\end{array}$ & $\begin{array}{r}-0.101 * * * \\
(-2.722)\end{array}$ & $\begin{array}{l}-0.074^{*} \\
(-1.752)\end{array}$ & $\begin{array}{l}-0.059 \\
(-1.438)\end{array}$ \\
\hline ISS recommendation & $\begin{array}{r}-0.113 * * \\
(-2.515)\end{array}$ & $\begin{array}{r}-0.101 * * \\
(-2.122)\end{array}$ & $\begin{array}{r}-0.092 * * * \\
(-4.906)\end{array}$ & $\begin{array}{r}-0.098 * * * \\
(-6.555)\end{array}$ \\
\hline Ln of total assets & $\begin{array}{l}-0.001 \\
\quad(-0.419)\end{array}$ & $\begin{array}{l}-0.000 \\
\quad(-0.055)\end{array}$ & $\begin{array}{l}-0.001 \\
(-0.312)\end{array}$ & $\begin{array}{r}-0.001 \\
\quad(-0.570)\end{array}$ \\
\hline Diversifying merger & $\begin{array}{l}0.019 \\
\quad(1.251)\end{array}$ & $\begin{array}{l}0.020 \\
\quad(1.245)\end{array}$ & $\begin{array}{l}0.006 \\
\quad(0.869)\end{array}$ & $\begin{array}{l}0.006 \\
\quad(0.826)\end{array}$ \\
\hline Cash payment (\%) & $\begin{array}{r}-0.008 \\
(-0.524)\end{array}$ & $\begin{array}{l}-0.011 \\
\quad(-0.693)\end{array}$ & $\begin{array}{r}-0.006 \\
(-0.669)\end{array}$ & $\begin{array}{l}-0.003 \\
(-0.276)\end{array}$ \\
\hline Free float $(\%)$ & & $\begin{array}{l}0.010 \\
\quad(0.374)\end{array}$ & & $\begin{array}{r}0.036 * * * \\
(3.728)\end{array}$ \\
\hline CEO voting rights $(\%)$ & & $\begin{array}{l}-0.018 \\
(-0.400)\end{array}$ & & $\begin{array}{r}-0.054 * * \\
(-2.384)\end{array}$ \\
\hline Director voting rights (\%) & & $\begin{array}{l}0.069 \\
\quad(1.028)\end{array}$ & & $\begin{array}{r}-0.031 \\
(-1.592)\end{array}$ \\
\hline Industry-fixed effects & Yes & Yes & Yes & Yes \\
\hline Year-fixed effects & Yes & Yes & Yes & Yes \\
\hline Number of observations & 141 & 141 & 243 & 243 \\
\hline$R^{2}$ & 0.367 & 0.377 & 0.202 & 0.244 \\
\hline
\end{tabular}

This table reports the results from regressions of voting dissent on abnormal returns on the day of the merger announcement and various control variables. I separate firms that are acquirers in an observed deal from those that are targets. Voting dissent is measured as the shares voted "Against" as a percentage of the sum of shares voted "For" and "Against," winsorized at the $1 \%$ level. Abnormal returns computed using the market model are winsorized at the $1 \%$ level. Mergers are classified as "diversifying" when acquirer and target firms have different two-digit SIC codes. Director voting rights denote all voting rights held by directors and executives, excluding the CEO. All regressions include industry- and year-fixed effects and White (1980) heteroskedasticity-robust standard errors. Significance at the 10, 5, and $1 \%$ levels is indicated by $*, * *$, and $* * *$, respectively

to this alteration. The signs and significance levels of all coefficient estimates remain unchanged, with the exception of the coefficient on the ISS recommendation, which is now significant at the $1 \%$ instead of $5 \%$ level for target firms, and the coefficient on director voting rights, which is now significant at the $10 \%$ level instead of being borderline insignificant for acquiring firms. As I have no observation at the upper bound of $100 \%$ voting dissent and only 10 target and 8 acquirer observations at the lower bound of $0 \%$ voting dissent (less than $5 \%$ of my sample) and due to the easier economic interpretation of results, I continue to use OLS regressions instead of tobit in the remainder of the paper.

In a second robustness test, I apply a probit regression model to my data. I define a dummy that indicates voting outcomes in the 90th dissent percentile, that is, above 


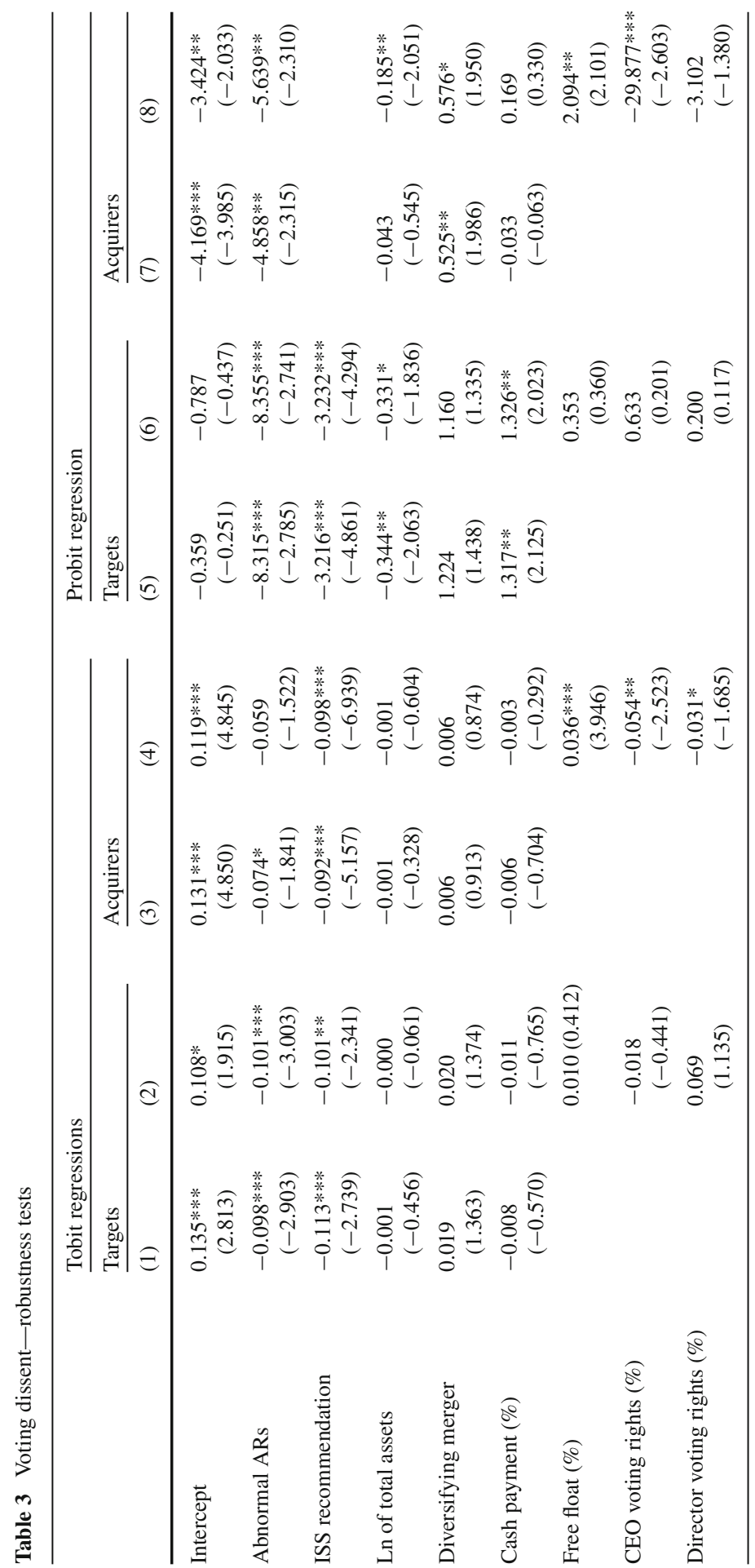




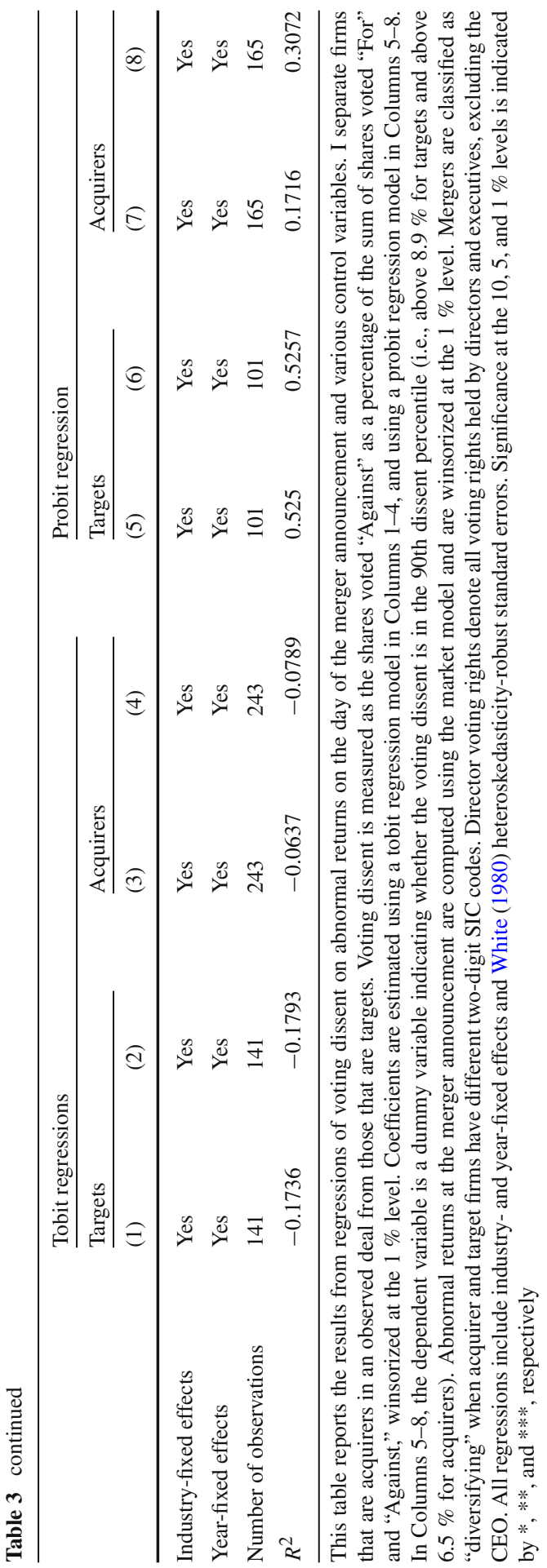




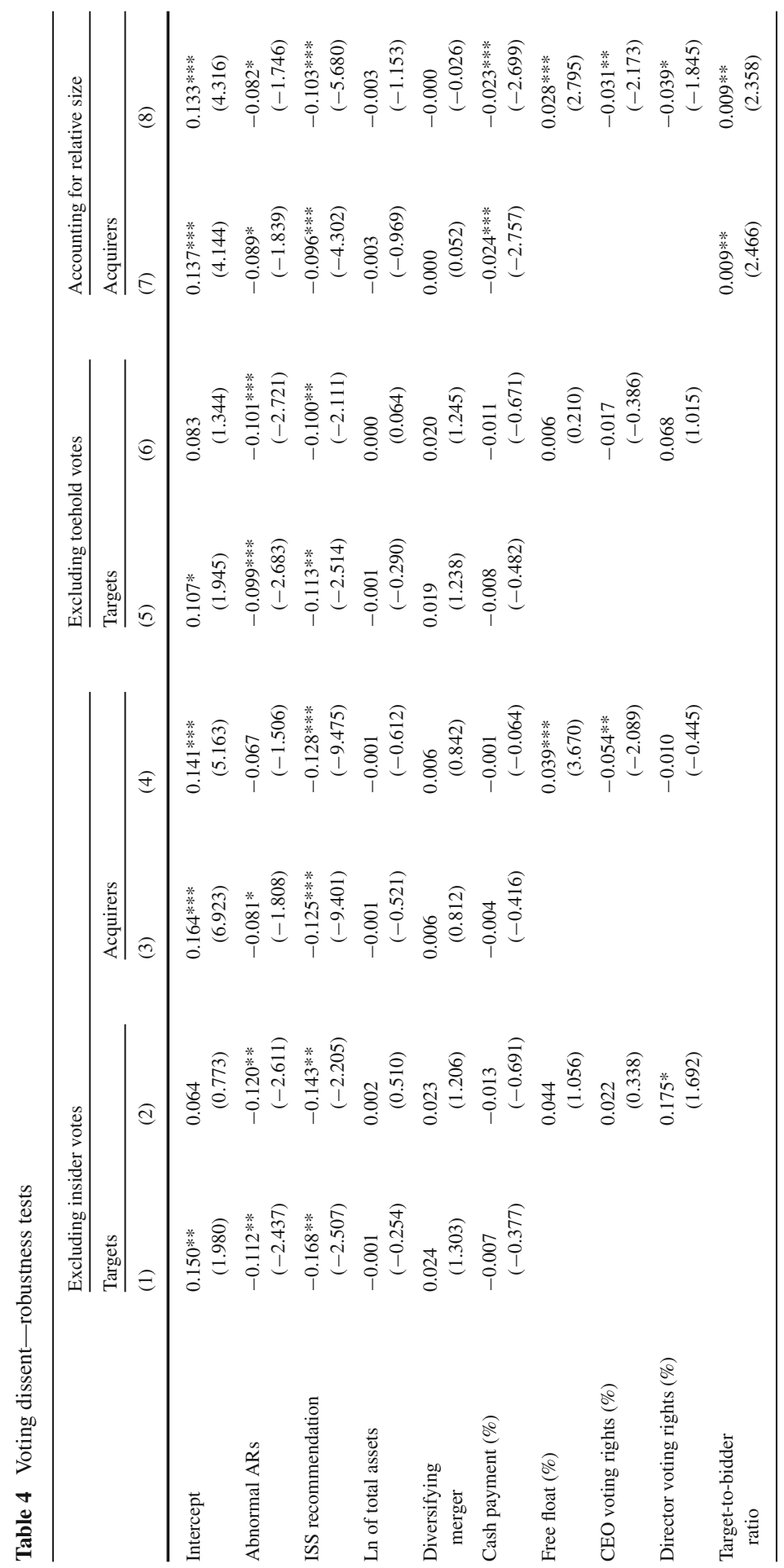




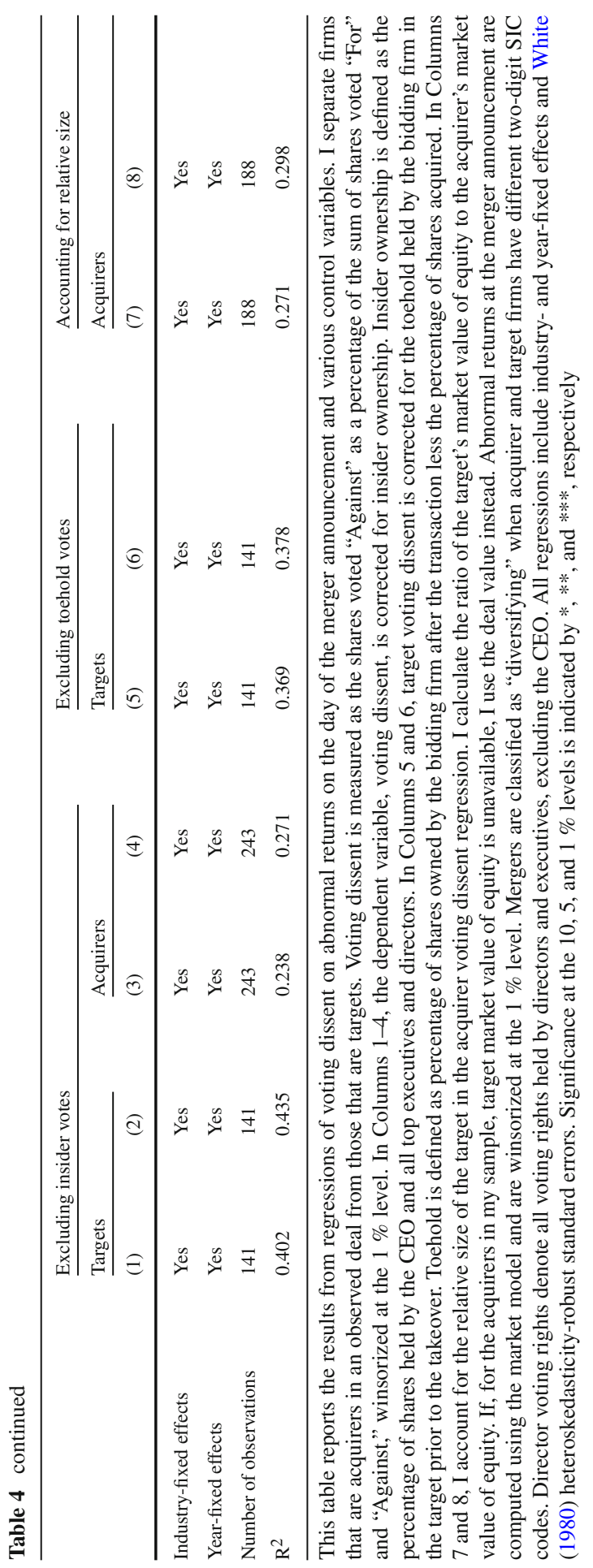


$8.9 \%$ for targets and $6.5 \%$ for acquiring firms. As reported in Columns 5-8 of Table 3, the results remain similar. Again, both the ISS recommendation and abnormal announcement returns are significantly negatively related to voting dissent across all regressions. In the analysis of target votes, the coefficient estimates remain qualitatively unchanged and have very similar significance levels. In the analysis of acquirer votes, there are two important differences compared to results reported in Table 2. First, the negative relationship between abnormal announcement returns and voting dissent is now significant at the $5 \%$ level in both specifications. Second, I find a significant positive relationship between diversifying mergers and voting dissent, indicating that shareholders oppose diversifying mergers to a higher degree. This is consistent with a long-standing strand of literature documenting the detrimental effect on value of diversifying mergers (e.g., Morck et al. 1990; DeLong 2001).

Third, I account for the ownership structure more directly by assuming that certain shareholder groups most likely vote in favor of a transaction. In Columns 1-4 of Table 4, I correct the percentage of shares voted "For" for the percentage of shares owned by insiders (CEO and directors). Additionally, in Columns 5 and 6, I adjust the target voting dissent measure for the toehold owned by the bidder prior to the transaction. I estimate the toehold for all target firms as the percentage of shares owned after the transaction less the percentage of shares acquired. On average, in my sample, acquirers hold a toehold stake of $1.4 \%$ in the target firms. My approach is similar to that of Becher et al. (2011). In their measure of outside shareholder support, they exclude voting rights held by managers and directors, as well as those held by financial advisors. Due to informational asymmetries, I expect such inside shareholders to be less sensitive to public information than the majority of small outside investors. Thus, the relationship I observe between proxy advisor recommendations and shareholder dissent, and between abnormal merger announcement returns and shareholder dissent, should be more pronounced when insider ownership and toehold are excluded. For example, for target firms, when accounting for insider ownership, the absolute coefficients on announcement day abnormal returns increase from 0.098 (0.101) in Column 1 (2) of Table 2 to 0.112 (0.120) in Column 1 (2) of Table 4. Similarly, the ISS recommendations dummy coefficient increases from $0.113(0.101)$ in Column 1 (2) of Table 2 to 0.168 (0.143) in Column 1 (2) of Table 4. The results are similar for acquirers in Columns 3 and 4 and when I directly account for bidder toeholds in the dependent variable in Columns 5 and 6. In Columns 7 and 8 of Table 4, I additionally include the target-to-bidder ratio, defined as the target market value of equity divided by the acquirer market value of equity, as the independent variable in the acquirer voting dissent regression. The target-to-bidder ratio is positively related to acquirer voting dissent, suggesting that shareholders might be afraid of management overextending itself. This is consistent with a comprehensive literature documenting the detrimental effect of managers' empire-building behavior (Jensen 1986; Masulis et al. 2007; Hope and Thomas 2008). Further, the magnitude and significance of the abnormal announcement return coefficient increase slightly when including the targetto-bidder ratio as a control variable. Further, cash payment is significantly negatively related to voting dissent at the $1 \%$ level, suggesting that acquiring firms' shareholders are relatively opposed to mergers that are paid for with stock rather than with cash. This is consistent with previous literature documenting higher announcement and long-run 
abnormal returns for cash-financed relative to stock-financed acquisitions (Travlos 1987; Loughran and Vijh 1997; Rau and Vermaelen 1998). Moreover, I find that director voting rights are significantly negatively linked to voting dissent, suggesting that directors vote alongside management. However, as controlling for the target-tobidder variable reduces sample size by 55 observations, I omit this variable in my main specification.

In unreported regressions, I also control for the number of bidders by defining a dummy variable that is equal to 1 if the number of bidders exceeds one. The mean number of bidders in my sample is 1.07 for target firms and 1.04 for acquirer firms. The coefficient on the number of bidders is insignificant; the other coefficients remain virtually unchanged.

To summarize, my first set of hypotheses asserts that mergers that experience higher abnormal announcement returns will receive less voting dissent. I expect this relationship to be economically more important for target than for acquiring firms. Moreover, I conjecture that the sensitivity of voting dissent to announcement returns is higher in firms with lower insider ownership. Consistent with the first two hypotheses, I find that both abnormal announcement returns and ISS recommendations are significantly negatively related to shareholder voting dissent. ${ }^{12}$ The observed relationship is robust to several changes in my specifications and stronger for target firms, when excluding ownership stakes held by insiders and the toehold owned by the acquiring firm, and when accounting for the relative sizes of target and acquirer.

\subsection{Voting outcome and abnormal meeting returns}

In this section, I analyze the effect of voting dissent on abnormal returns around the shareholder meeting. Similar to Cai and Walkling (2011) and Cunat et al. (2012), I expect that the meeting outcome might not always be fully anticipated. As the voting results are not always available on the day of the meeting, I estimate the abnormal returns for an event window that includes the day of the shareholder meeting and one day after. I, therefore, require firms to have at least two days of share price data following the meeting. Merger votes are held either at an annual meeting or at a special meeting. At annual meetings, shareholders often are required to elect directors and ratify auditors. I exclude meetings at which other issues (apart from the merger) are up for vote. I include similar control variables as in Table 2 augmented by voting dissent.

The results are reported in Table 5. I find a strong positive relationship between voting dissent and cumulative abnormal returns on the meeting date for both target and acquiring firms. The relationship is significant at the $1 \%$ level for both target and

\footnotetext{
12 This suggests that shareholders take market opinion into account when making their voting decisions, in spite of possible management lobbying efforts. If a merger is not well received by the market upon announcement, management presumably has an incentive to "turn" shareholders' opinion. Prior to the annual meeting on May 20, 2013, J.P. Morgan Chase Bank had successfully lobbied behind the scenes to avoid the pass of a shareholder proposal to separate the chairman and CEO positions. The lobbying involved meetings and several conference calls with big investors (Craig and Silver-Greenberg 2013). Despite the proposal being backed by a number of large pension funds and proxy advisors, it did not pass. My findings show that, in spite of possible management lobbying efforts, votes significantly reflect both market opinion and ISS recommendations.
} 
Table 5 Abnormal cumulative returns on the meeting date

\begin{tabular}{|c|c|c|c|c|}
\hline & \multicolumn{2}{|l|}{ Targets } & \multicolumn{2}{|l|}{ Acquirers } \\
\hline & (1) & (2) & (3) & (4) \\
\hline Intercept & $\begin{array}{l}0.016 \\
\quad(0.792)\end{array}$ & $\begin{array}{l}0.028 \\
\quad(1.120)\end{array}$ & $\begin{array}{r}-0.106^{* * * *} \\
(-3.353)\end{array}$ & $\begin{array}{r}-0.123 * * * \\
(-3.456)\end{array}$ \\
\hline Voting dissent & $\begin{array}{r}0.135 * * * \\
(2.744)\end{array}$ & $\begin{array}{r}0.142 * * * \\
(2.791)\end{array}$ & $\begin{array}{r}0.241 * * * \\
(4.576)\end{array}$ & $\begin{array}{r}0.240 * * * \\
(5.142)\end{array}$ \\
\hline Abnormal ARs & $\begin{array}{l}0.025 \\
\quad(1.260)\end{array}$ & $\begin{array}{l}0.029 \\
\quad(1.460)\end{array}$ & $\begin{array}{l}0.116 \\
\quad(1.470)\end{array}$ & $\begin{array}{l}0.103 \\
\quad(1.191)\end{array}$ \\
\hline ISS recommendation & $\begin{array}{l}-0.002 \\
(-0.208)\end{array}$ & $\begin{array}{l}-0.005 \\
(-0.379)\end{array}$ & & \\
\hline Ln of total assets & $\begin{array}{l}0.000 \\
(0.079)\end{array}$ & $\begin{array}{l}-0.000 \\
\quad(-0.063)\end{array}$ & $\begin{array}{l}0.002 \\
\quad(1.198)\end{array}$ & $\begin{array}{l}0.004^{*} \\
\quad(1.885)\end{array}$ \\
\hline Diversifying merger & $\begin{array}{l}0.001 \\
\quad(0.187)\end{array}$ & $\begin{array}{l}0.001 \\
\quad(0.145)\end{array}$ & $\begin{array}{l}-0.001 \\
\quad(-0.084)\end{array}$ & $\begin{array}{l}0.000 \\
\quad(0.044)\end{array}$ \\
\hline Cash payment $(\%)$ & $\begin{array}{r}-0.022 * * * \\
(-3.157)\end{array}$ & $\begin{array}{r}-0.022 * * * \\
(-2.996)\end{array}$ & $\begin{array}{l}0.014 \\
\quad(0.905)\end{array}$ & $\begin{array}{l}0.018 \\
\quad(1.054)\end{array}$ \\
\hline Free float $(\%)$ & & $\begin{array}{r}-0.008 \\
(-0.585)\end{array}$ & & $\begin{array}{l}0.014 \\
\quad(0.573)\end{array}$ \\
\hline CEO voting rights $(\%)$ & & $\begin{array}{l}0.019 \\
\quad(0.796)\end{array}$ & & $\begin{array}{l}-0.059 \\
(-1.374)\end{array}$ \\
\hline Director voting rights (\%) & & $\begin{array}{l}-0.024 \\
(-1.026)\end{array}$ & & $\begin{array}{l}0.104 \\
\quad(1.621)\end{array}$ \\
\hline Industry-fixed effects & Yes & Yes & Yes & Yes \\
\hline Year-fixed effects & Yes & Yes & Yes & Yes \\
\hline Number of observations & 109 & 109 & 90 & 90 \\
\hline$R^{2}$ & 0.411 & 0.422 & 0.312 & 0.364 \\
\hline
\end{tabular}

This table reports the results from regressions of the cumulative abnormal returns on the day of the shareholder meeting and subsequent day on the voting dissent at the shareholder meeting and various control variables. I exclude meetings at which other issues (apart from the merger) are up for a vote. I separate firms that are acquirers in an observed deal from those that are targets. Voting dissent is measured as the shares voted "Against" as a percentage of the sum of shares voted "For" and "Against," winsorized at the $1 \%$ level. Abnormal returns are computed using the market model and are winsorized at the $1 \%$ level. Mergers are classified as "diversifying" when acquirer and target firms have different two-digit SIC codes. Director voting rights denote all voting rights held by directors and executives, excluding the CEO. All regressions include industry- and year-fixed effects and White (1980) heteroskedasticity-robust standard errors. Significance at the 10,5 , and $1 \%$ levels is indicated by *, **, and ***, respectively

acquiring firms and across all regressions. This finding is in line with Hypothesis $2 b$, asserting that mergers that receive greater voting dissent will have higher abnormal meeting returns.

A possible explanation for this positive market reaction to greater voting dissent at the shareholder meeting is that the abnormal returns following the shareholder meeting reflect the resolution of the residual uncertainty. Asquith (1983) argues that price movements between announcement and completion date reflect changes in the probability of merger completion. He shows that a decrease in this probability harms the stockholders of both target and acquiring firms. Arguably, the announcement return 
does not reflect the entire value but is, rather, "discounted" based on completion probability. Even if merger completion remains contingent on regulatory approval after the meeting, the shareholder vote resolves an important amount of uncertainty that might be reflected in abnormal returns. I use the length of the negotiation period (measured as the number of days between the merger announcement and meeting date) to proxy for the degree of negotiation complexity and uncertainty that is resolved at the meeting. If uncertainty plays a role, I would expect the relationship between voting dissent and market reaction to be more pronounced for mergers with a longer negotiation period. To test this, I split my sample at the median negotiation period of 126 days and run separate regressions for both subsamples. The results are reported in Table 6 and support the uncertainty explanation. In the below-median negotiation period subsample (Columns 1-4), all coefficients on voting dissent are statistically insignificant. In contrast, in the high-uncertainty subsample (Columns 5-8), the coefficients on voting dissent are statistically significant at the $1 \%$ level for acquirers and at the $5 \%$ level (and borderline insignificant) for target firms.

To summarize, I find that voting dissent is positively related to cumulative abnormal returns on the meeting date. The observed relationship between voting dissent and subsequent abnormal returns is statistically significant only for the subsample of deals facing higher uncertainty, as measured by above-median negotiation period length. For these deals, a "pass" vote by shareholders was presumably not fully anticipated.

\subsection{Voting outcome and long-term performance}

In this section, I estimate the relationship between voting dissent and long-run abnormal merger returns. I estimate abnormal returns starting at the beginning of the first month following formal completion of the merger. I exclude firms that are not acquirers and that have data available for less than 2 (or 5) years after the merger completion. My final sample consists of 194 acquiring firm observations for the 2-year, and 79 acquiring firm observations for the 5-year, holding period. I use monthly data to estimate the two- and 5-year buy-and-hold abnormal returns based on the market model, the Fama and French (1993) three-factor model, and the Carhart (1997) four-factor model. Both shareholder dissent and other factors that may at the same time impact shareholder dissent, as well as firm performance, are potentially related to long-term abnormal returns. I, therefore, control for a set of variables that include voting dissent, abnormal merger announcement returns, firm size, a dummy variable for diversifying mergers, and the percentage of deal value paid for with cash.

The results are reported in Table 7. Abnormal returns are estimated using the market model in Columns 1 and 4, the Fama-French three-factor model in Columns 2 and 5, and the Carhart four-factor model in Columns 3 and 6. In spite of the limited sample size and the lower variation in both voting dissent and abnormal merger announcement returns for acquiring firms (compared to target firms), I find that voting dissent is negatively related to long-run abnormal performance. For a 2-year holding period, this relationship is significant at the $5 \%$ level across all three models. For a 5-year period, this relationship is significant at the $10 \%$ level when using the market model or the Fama-French three-factor model, but borderline insignificant when using the Carhart four-factor model. Thus, even after controlling for other firm and deal char- 


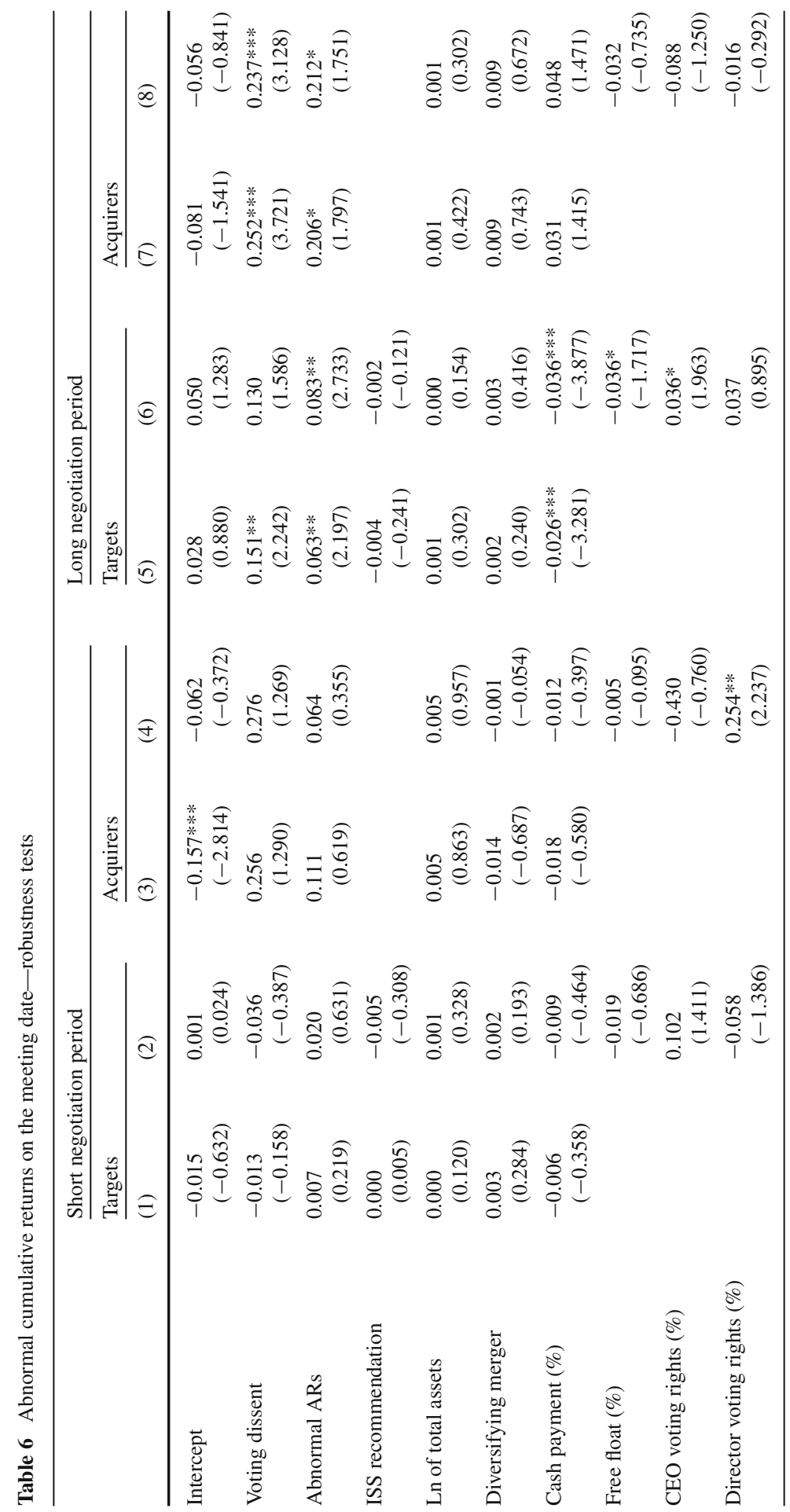




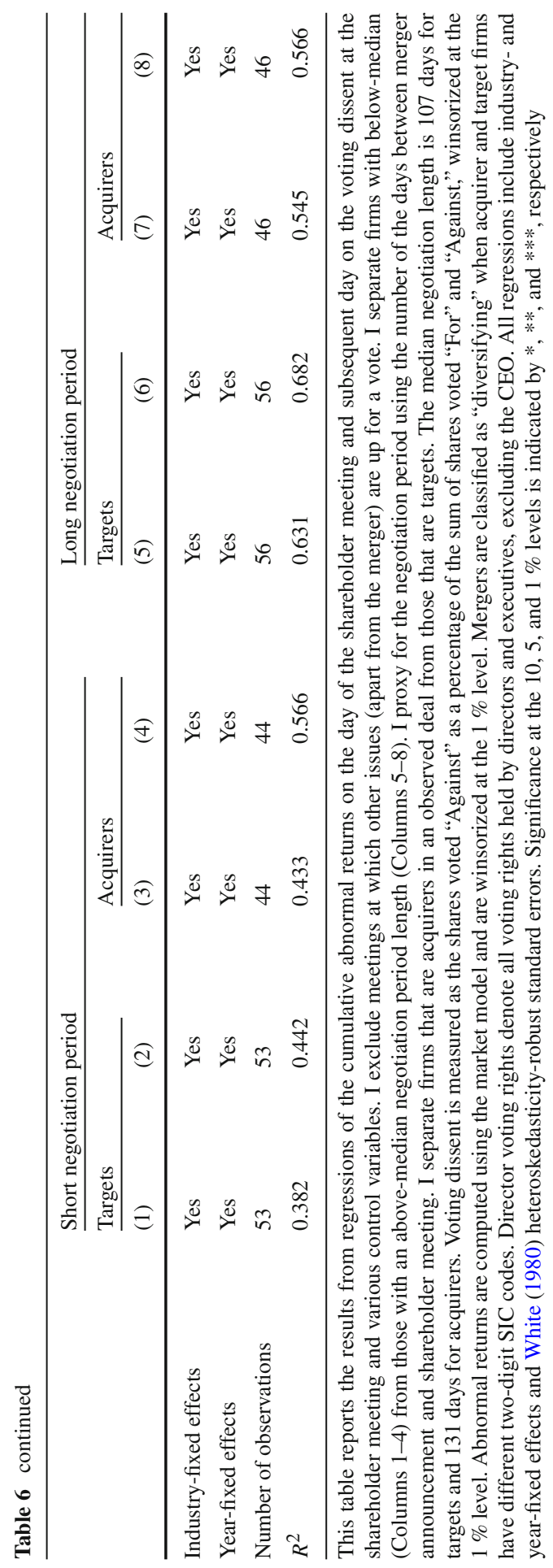




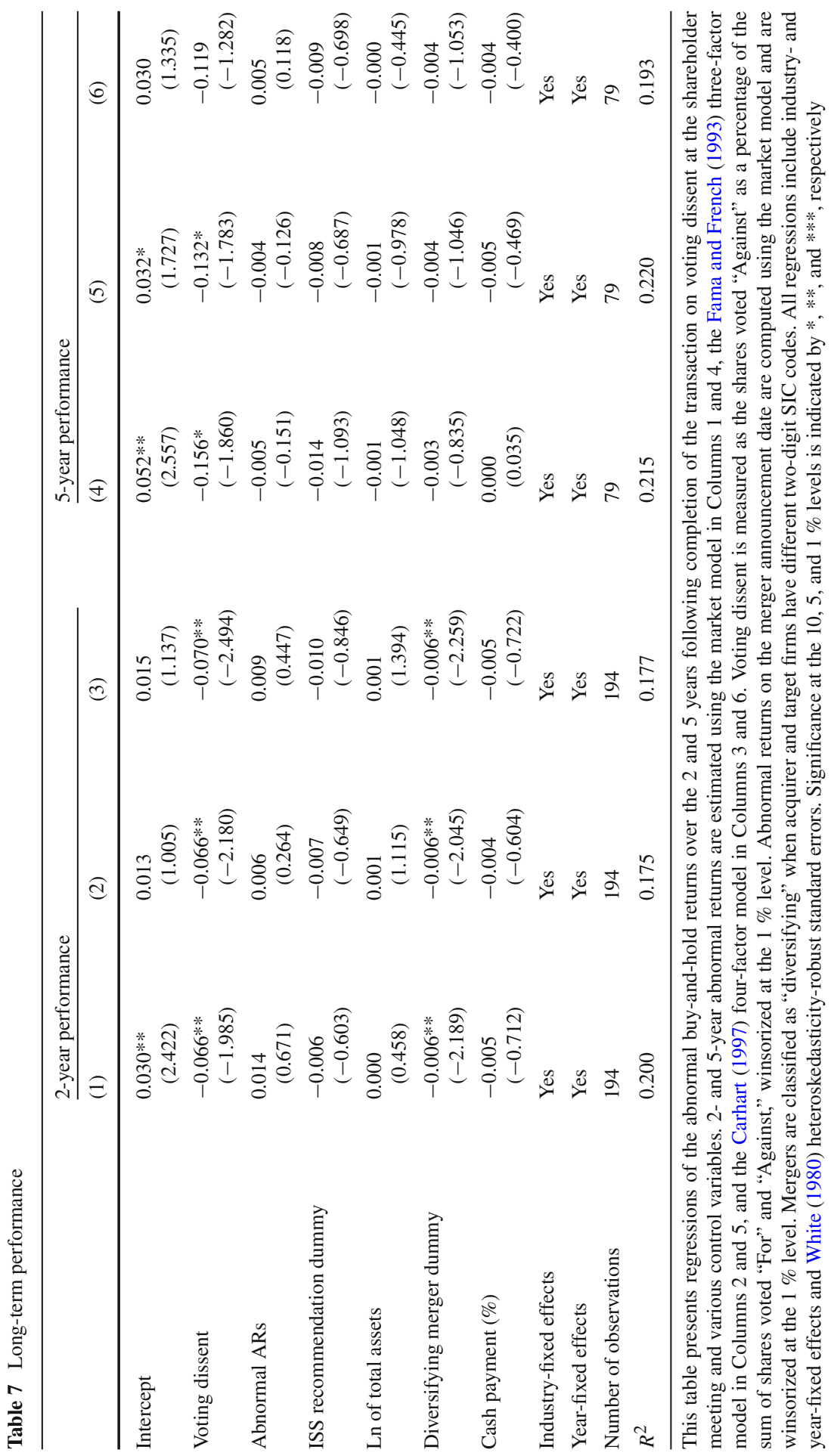


acteristics, shareholder dissent still explains a significant portion of long-term merger performance.

My third hypothesis asserts that mergers that receive greater voting dissent will perform worse in the long term. Consistent with this hypothesis, I find that voting dissent is negatively related to long-run abnormal merger performance. Mergers receiving stronger support from shareholders perform better over both 2- and 5-year holding periods. To some extent, my evidence suggests that shareholders are able to distinguish between "good" and "bad" mergers in the long term.

\section{Conclusion}

In this study, I investigate whether both target and acquirer shareholder votes on mergers and acquisitions relate to the announcement day abnormal returns and whether the voting outcome has implications for short- and long-run performance. Using a dataset comprising 384 shareholder meetings on mergers and acquisitions by both target and acquiring firms, I document a robust negative relationship between abnormal returns upon merger announcement, as well as recommendations by the Institutional Shareholder Services (ISS), and shareholder voting dissent. The observed relationship is robust to several changes in my specifications and strongest for target firms and when excluding ownership stakes held by insiders and the toehold owned by the acquiring firm. These results suggest that shareholders take into account both advisor opinions and market beliefs on a merger transaction when making their voting decisions. My empirical analyses further reveal that voting dissent is strongly positively related to cumulative abnormal returns on the meeting date. Hence, shareholder voting is viewed by the market as a source of uncertainty, which is reflected in stock prices. The observed relationship between voting dissent and subsequent abnormal returns is statistically significant only for deals that face a high degree of uncertainty, as measured by the length of the negotiation period. This suggests that stronger shareholder dissent is associated with a higher fraction of residual uncertainty that is resolved upon the merger vote. Furthermore, I find that voting dissent is negatively related to long-run abnormal merger performance, suggesting that voting dissent has some predictive power for long-term merger performance.

Acknowledgments I thank the anonymous referee as well as Yakov Amihud, Manuel Ammann, Tanja Artiga Gonzales, Martin Brown, Günter Franke, Jens Jackwerth, Roni Michaely, David Oesch, Markus Schmid, Dustin Schütte, Philip Valta, and seminar participants at the University of St. Gallen for helpful comments and suggestions.

\section{References}

Agrawal, A., Jaffe, J., Mandelker, G.: The post-merger performance of acquiring firms: a re-examination of an anomaly. J. Financ. 47, 1605-1621 (1992)

Amihud, Y., Lev, B., Travlos, N.: Corporate control and the choice of investment financing: the case of corporate acquisitions. J. Financ. 45, 603-616 (1990)

Andrade, G., Mitchell, M., Stafford, E.: New evidence and perspectives on mergers. J. Econ. Perspect. 15, 103-120 (2001)

Asquith, P.: Merger bids, and stockholder returns. J. Financ. Econ. 11, 51-83 (1983) 
Becher, D., Cai, J., Ouyang, W.: Do shareholders listen? M\&A Advisor Opinions and Shareholder Voting, Working Paper, Drexel University (2011)

Bizjak, J., Marquette, C.: Are shareholder proposals all bark and no bite? Rescind poison pills. J. Financ. Quant. Anal. 33, 499-521 (1998)

Cai, J., Garner, J., Walkling, R.: Electing directors. J. Financ. 64, 2389-2421 (2009)

Cai, J., Walkling, R.: Shareholders' say on pay: does it create value? J. Financ. Quant. Anal. 46, 299-339 (2011)

Carhart, M.: On persistence in mutual fund performance. J. Financ. 52, 57-82 (1997)

Choi, S., Fisch, J., Kahan, E.: The power of proxy advisors: myth or reality. Emory Law J. 59, 869-918 (2010)

Craig, S., Silver-Greenberg, J.: Strong lobbying helps Dimon Thwart a shareholder challenge. http://deal book.nytimes.com/2013/05/21/jpmorgan-seen-to-defeat-effort-to-split-top-2-jobs-at-bank/ (2013)

Cunat, V., Gine, M., Guadalupe, M.: The vote is cast: the effect of corporate governance on shareholder value. J. Financ. 67, 1943-1977 (2012)

Cunat, V., Gine, M., Guadalupe, M.: Say pays! Shareholder voice and firm performance, Working Paper. London School of Economics and Political Science (2013)

Del Guercio, D., Seery, L., Woidtke, T.: Do boards pay attention when institutional investors "just vote no"? J. Financ. Econ. 90, 84-103 (2008)

DeLong, G.: Stockholder gains from focusing versus diversifying bank mergers. J. Financ. Econ. 59, 221252 (2001)

Dimson, E., Marsh, P.: Event study methodologies and the size effect: the case of UK press recommendations. J. Financ. Econ. 17, 113-142 (1986)

Ertimur, Y., Ferri, F., Maber, D.: Reputation penalties for poor monitoring of executive pay: evidence from option backdating. J. Financ. Econ. 104, 118-144 (2012)

Ertimur, Y., Ferri, F., Oesch, D.: Shareholder votes and proxy advisors: evidence from say on pay. J. Account. Res. 51, 951-996 (2013)

Fama, E., French, K.: Common risk factors in the returns on stocks and bonds. J. Financ. Econ. 33, 3-56 (1993)

Ferri, F., Maber, D.: Say on pay votes and CEO compensation: evidence from the UK. Rev. Financ. 17, 527-563 (2013)

Ferri, F., Sandino, T.: The impact of shareholder activism on financial reporting and compensation: the case of employee stock options expensing. Account. Rev. 84, 433-466 (2009)

Fischer, P., Gramlich, J., Miller, B., White, H.: Investor perceptions of board performance: evidence from uncontested director elections. J. Account. Econ. 48, 172-189 (2009)

Gillan, S., Starks, L.: Corporate governance proposals and shareholder activism: the role of institutional investors. J. Financ. Econ. 57, 275-295 (2000)

Gordon, L., Pound, J.: Information, corporate governance proposals. J. Financ. 48, 697-718 (1993)

Hope, O., Thomas, W.: Managerial empire building and firm disclosure. J. Account. Res. 46, 591-626 (2008)

Ibbotson, R.: Price performance of common stock new issues. J. Financ. Econ. 3, 235-272 (1975)

Jensen, M.: Agency cost of free cash flow. Corporate finance, and takeovers. Am. Econ. Rev. 76, 323-329 (1986)

Karpoff, J., Malatesta, P., Walkling, R.: Corporate governance and shareholder initiatives: empirical evidence. J. Financ. Econ. 42, 365-395 (1996)

Lakonishok, J., Vermaelen, T.: Anomalous price behavior around repurchase tender offers. J. Financ. 45, 455-477 (1990)

Loughran, T., Vijh, A.: Do long-term shareholders benefit from corporate acquisitions? J. Financ. 52, 17651790 (1997)

MacKinlay, A.: Event studies in economics and finance. J. Econ. Lit. 35, 13-39 (1997)

Martin, K., Thomas, R.: When is enough, enough? CEO compensation. J. Corp. Financ. 11, 61-83 (2005)

Masulis, R., Wang, C., Xie, F.: Corporate governance and acquirer returns. J. Financ. 62, 1851-1889 (2007)

Moeller, S., Schlingemann, F., Stulz, R.: Wealth destruction on a massive scale? The recent merger wave. J. Financ. 60, 757-782 (2005)

Morck, R., Shleifer, A., Vishny, R.: Do managerial objectives drive bad acquisitions? J. Financ. 45, 31-48 (1990)

Morgan, A., Poulsen, A., Wolf, J.: The evolution of shareholder voting for executive compensation schemes. J. Corp. Financ. 12, 715-737 (2006) 
Rau, P., Vermaelen, T.: Glamour, acquiring firms. J. Financ. Econ. 49, 223-253 (1998)

Travlos, N.: Corporate takeover bids, stock returns. J. Financ. 42, 943-963 (1987)

White, H.: A heteroskedasticity-consistent covariance matrix estimator and a direct test for heteroskedasticity. Econometrica 48, 817-838 (1980)

Laura Sophie Henning is a Ph.D. student at the University of St. Gallen in Switzerland. She received a Diploma in Management Science from ESCP Europe in Paris. Her research areas are empirical corporate finance and corporate governance. 